\title{
TRAITS CORRELATED WITH DIFFERENTIAL DROUGHT TOLERANCE BETWEEN SELECTED SOYBEAN CULTIVARS
}

Heba M. Ibrahim

Botany Department, Faculty of Agriculture, Mansoura University,35516, Mansoura, Egypt

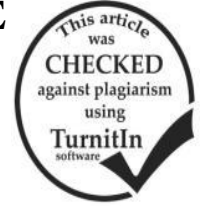

\section{ABSTRACT}

The present study aimed to determine differences in drought tolerance between three widely-cultivated soybean cultivars in Egypt. Two field experiments were conducted at the experimental farm and laboratories of the Agric. Bot. Dept., Fac. of Agric., Mansoura Univ., Egypt during the two growing seasons of 2013 and 2014. The experimental design was a split-plot with two irrigation regimes in the main plots (control and water stress) and three cultivars in the sub-plots (Giza 22, Giza 35 and Giza 111).

Results indicated that drought stress decreased seed yield, dry biomass, relative growth rate (RGR), net assimilation rate (NAR), relative water content (RWC), membrane stability index (MSI), whereas increased phenols, flavonoids, anthocyanins and proline content differentially between the tested cultivars. Drought tolerance index of cv. Giza 111 was significantly higher than other studied cultivars and this was accompanied with higher biomass accumulation, RGR, NAR, RWC, MSI as well as higher content of phenols, flavonoids, anthocyanins and proline. It was concluded that cv Giza 111 is better-adapted to drought-affected areas and could be utilized in breeding programs aiming to increase drought tolerance in soybean.

\section{INTRODUCTION}

Soybean is the main oil seed crop worldwide and providing the main source of oil and plant protein. In Egypt, expanding soybean cultivation and enhancing its yield can bridge the gap between the demand and supply of edible oil and protein. The yield of soybean is a function of many factors, the most notably of which are cultivar and water availability and the later has a direct relationship with crop yield (Kobraee et al., 2011). Seed yield can be reduced by $24-50 \%$ due to drought stress (Sadeghipour and Abbass, 2012).

To facilitate cultivation of soybean in droughtaffected regions, it is important to differentiate between soybean cultivars according to their drought tolerance potential. Differential drought tolerance between soybean cultivars were reported (Adejare and Umebese, 2008; Stolf-Moreira et al., 2010; Tint et al., 2011; Abd El-Mohsen et al., 2013). Differentiating soybean cultivars for drought tolerance based on yield though common, is not practical for drought tolerance selection as this trait is controlled by a complex interaction between genotype and environment. Hence, selection for more simple traits positively correlated with yield would be more feasible approach. Various characters were tested with regard to their ability to differentiate between certain soybean genotypes for drought tolerance. Sugars accumulation capacity and higher number of trichomes/unit leaf area characterized drought-tolerant genotypes (Adejare and Umebese, 2008). Photosythetic rate and stomatal conductance differentiated between soybean cultivars with regard to drought tolerance (Stolf-Moreira et al., 2010). In addition, dry matter accumulation capacity, shoot moisture content and electrolyte leakage were used to rank various soybean cultivars for drought tolerance (Tint et al., 2011). Nevertheless, differential drought tolerance between widely-cultivated soybean cultivars in Egypt and its correlation with cultivar-specific characters is less understood. Therefore, the present investigation was undertaken to determine differences in drought tolerance between three widely-cultivated soybean cultivars in Egypt as well as their characteristic attributes correlated with drought tolerance.

\section{MATERIALS AND METHODS}

\section{Plant materials and cultivation:}

The current investigation was carried out at the Experimental Farm and Labs. of the Agric. Botany Dept., during the two growing seasons 2013 and 2014. Bradyrhizobium-inoculated seeds of soybean cultivars Giza 22 (G22), Giza 35 (G35) and Giza 111 (G111) were obtained from field crops Research Institute, Agric. Res. Center, Egypt. Sowing was done on 6 and 8 May during the two growing seasons of 2013 and 2014, respectively. Experimental design was a split plot design with three replicates. The main plots were assigned to irrigation regimes (control and water-stress) whereas subplots were assigned to cultivars. The experimental plot consisted of four rows, $3.0 \mathrm{~m}$ long and $0.6 \mathrm{~m}$ apart, with an area of $7.2 \mathrm{~m}^{2}$. Seeds were sown in hills, $20 \mathrm{~cm}$ apart, 3 seeds/ hill, and thinned two weeks after sowing to leave 2 plants/ hill. Main physical and chemical characteristics of the experimental soil shown in Table (1) were estimated according to Hoddinott and Lamb (1990).

Table (1) ${ }^{*}$. Mechanical and chemical analysis of the used soil (average of the two growing seasons).

\begin{tabular}{lccccccccc}
\hline CS \% & FS \% & S \% & C \% & CaCO $_{3} \%$ & OM \% & TN\% & AP ppm & EK ppm & TSS \% \\
9.9 & 28.6 & 27.5 & 34.0 & 2.5 & 2.3 & 0.15 & 18 & 226 & 0.18 \\
\hline
\end{tabular}
*CS, Coarse sand; FS, Fine sand; S, Silt; C, Clay; OM, Organic matter; TN, total N; AP, available P; EK, exchangeable K; TSS, total soluble solutes. 
Control and drought-stress plots were irrigated in the same way (at 10-days intervals during May and 7days intervals thereafter) except that in water-stress plots, irrigation was withheld for 15 days starting at 45 days after sowing (DAS). At the $61^{\text {th }}$ DAS, soil samples were taken from the top $30 \mathrm{~cm}$ to assess water status in control and water-stressed plots. Water potential ( $\Psi \mathrm{s})$ was -0.18 and -0.77 bar in control and water-stressed plots, respectively.

\section{Recoded parameters and analyses}

At 61 DAS, leaf samples were taken from 4 plants in each replicate to determine relative water content (RWC), membrane stability index (MSI) and concentration of phenols, flavonoids, anthocyanins and proline. Moreover 12 plants, selected randomly from each treatment, four plants from each replicate, were used for determination of biomass and leaf area. Another sample was taken 10 days later to estimate biomass and leaf area. Data of the two samples were used to calculate relative growth rate (RGR) and net assimilation rate (NAR) according to Radford (1967)'s formulae as follows:

$$
\text { RGR }=\left(\log _{\mathrm{e}} \mathrm{DW}-\log _{\mathrm{e}} \mathrm{DW}\right) / \mathrm{t}_{2}-\mathbf{t}_{1}
$$

$\mathbf{N A R}=\left[\left(\mathbf{W}_{2}-\mathbf{W}_{1}\right)\left(\log _{\mathrm{e}} \mathbf{A}_{2}-\log _{\mathrm{e}} \mathbf{A}_{1}\right)\right] /\left[\left(\mathbf{A}_{2}-\mathbf{A}_{1}\right)\left(\mathbf{t}_{2}-\mathbf{t}_{1}\right)\right]$

Stress tolerance index (STI) was calculated according to Fernandez (1992) 's formula:

$$
\mathbf{S T I}=\frac{(y s)(y p)}{(y p)^{2}}
$$

\section{Where}

yp $=$ yield of a given cultivar in non-stress environment; ys - yield of a given cultivar in drought-stressed environment, ỳp = mean yield of all cultivars in a non-stressed environment.

Relative water content (RWC) was determined by the method of Gonzalez and Gonzalez-Vilar (2001) as follows:

$$
\mathbf{R W C}=\frac{F W-D W}{T W-D W} \times \mathbf{1 0 0}
$$

\section{where}

$\mathrm{FW}=$ fresh weight, $\mathrm{DW}=$ dry weight, $\mathrm{TW}=$ turgid weight. For determination of turgid weight, leaf disks were submerged for $8 \mathrm{~h}$ in distilled water, thereafter they were blotted dry gently and weighed. Total phenols content in the leaves was estimated by the method of Folin-Ciocalteu reagent using gallic acid as standard according to Gao et al., (2000) and expressed as gallic acid equivalent.Total flavonoids and anthocyanins content was determined by extraction in acidified methanol (methanol: water: $\mathrm{HCl}, 78: 20: 2 \mathrm{v} / \mathrm{v}$ ) for $24 \mathrm{~h}$ at $4^{\circ} \mathrm{C}$ as described by Jordan et al. (1994). The absorbance of the filtered extract was estimated at $320 \mathrm{~nm}$ and $530 \mathrm{~nm}$ for flavonoids and anthocyanins, respectively. Proline was determined according to the method of Bates et al. (1973). $0.5 \mathrm{~g}$ of leaf tissue was homogenized with $3 \%$ sulfosalicylic acid and estimated using ninhydrin reagent. The absorbance of fraction with toluene aspired from liquid phase was determined using T-60 U spectrophotometer at $520 \mathrm{~nm}$.

\section{Leaf epidermal and architectural features}

Abaxial and adaxial epidermal strips were prepared by the method of Weyers and Travis (1981) whereas leaf architectural and calcium oxalate crystals characteristics were studied in leaf clearings prepared according to Hickey (1973). The blades of the two lowermost leaflets from the $2^{\text {nd }}$ mature leaf from plant top were taken from 4 different plants selected randomly from each replicate. Two microscopic fields from each leaflet were checked for counting number of stomata and hairs as well as for estimating areoles and crystals number and dimensions. So, data are mean of 48 readings. Quantitative data were obtained using a calibrated eyepiece micrometer.

\section{Statistical analysis:}

Analysis of variance (ANOVA) was applied to determine the significance of the results using the statistical package for Social Sciences (SPSS) version 16.0 software (SPSS, Inc, Chicago, IL, USA). Data are presented as pooled data of the two growing seasons. Duncan's Multiple Range Test was applied to determine significant differences between means when ANOVA was significant at $\mathrm{P} \leq 0.05$. Correlation analysis was also conducted to determine correlations between selected estimated attributes and yield under water stress.

\section{RESULTS}

\section{Growth and seed yield}

Drought stress decreased seed yield along with biomass accumulation, RGR and NAR of all soybean cultivars compared to the control. The only exception is NAR in cv. Giza 111 where no significant difference was detected (Table 2). Seed yield differed significantly between cultivars either under control or water stress conditions. Under water stress, yield of cv Giza 111 was significantly higher than that of cv Giza 35, and Giza 22. In addition, cv Giza 111 had the highest drought tolerance index (DTI) whereas Giza 35 had the lowest DTI. However, the difference between DTI in cv Giza 111 and Giza 22 was insignificant. There were no significant differences between soybean cultivars growing under control conditions in either biomass, RGR or NAR. However, under water stress condition, there was a significant difference between cv Giza 111 and Giza 35 in all growth attributes whereas the corresponding differences between cv Giza 111 and Giza 22 were insignificant. In addition, though biomass, RGR and NAR recorded higher values in cv Giza 22 compared with cv Giza 35 under water stress condition, there were no significant differences between both cultivars.

\section{Biochemical constituents}

Data in Table (3) illustrate that cultivars grown under non-stress conditions showed no significant differences regarding RWC, MSI, phenols, flavonoids and proline contents. However, anthocyanins content was significantly higher in cv G 35 than that in the other two cultivars under non-stress conditions (Table 3). Under stress conditions, significant differences between cvs were recorded in all studied biochemical characters, 
where higher values from RWC, MSI, phenols,flavonoids,anthocyanins and proline contents were recorded in cv Giza 111 compared with the other two cultivars, with the corresponding values in cv G 22 came in the second order in this respect.

\section{Leaf epidermal features}

Data presented in Table (4) show that number of stomata and hairs per unit area did not differ significantly between cultivars growing under nonstress conditions. In all cultivars drought stress had no significant effect on number of stomata on abaxial surface whereas significantly reduced number of stomata on the adaxial surface. On the other hand, hairs number/unit area was significantly increased in all cultivars under water stress (Fig 1). Hairs density on both surfaces was highest in cv Giza 111 under water stress. The lowest number of hairs in water-stressed plants was recorded in cvs Giza 35 and Giza 22 on abaxial and adaxial surface, respectively.

\section{Leaf architecture and crystals deposition}

In leaves of control plants, areole dimensions were not significantly different between the studied cultivars whereas areoles number/ unit blade area was significantly higher in cv G 111 compared with cv G 35 (Table 5). On the other hand, calcium oxalate crystals number was significantly lower in leaves of cv G 111 compared with cv G 35 though no significant differences were recorded regarding crystal dimensions (length and width).Water stress significantly increased areoles number whereas decreased areole dimensions in all cultivars except cv G 35. In addition, leaves of all cultivars subjected to water stress contained significantly higher number of calcium oxalate crystals with higher dimensions compared with those of control plants (Fig 1). Under water stress condition, cv G 111 was diagnosed by higher number of both areoles and crystals/ unit blade area as well as by a higher dimensions of Crystals comared with the other two cultivars though the difference was only significant in comparison with cv G 35. On the other hand, areole dimensions in water-stressed cv G 111 were lower compared with those in the other two cultivars, and the difference was only significant compared with cv G 35 .

\section{Correlation coefficients between seed yield and} estimated attributes

Table (6) shows that stress yield was positively and significantly correlated with biomass $(\mathrm{r}=0.79 * *)$, MSI $\left(r=0.69^{*}\right)$, phenols content $(r=0.60 *)$, flavonoids content $\left(\mathrm{r}=0.56^{*}\right)$, proline content $\left(\mathrm{r}=0.63^{*}\right)$ and number of hairs/unit area $(\mathrm{r}=0.64 *)$. In addition, RGR, NAR and RWC were positively and significantly correlated with yield under drought stress. On the other hand, correlation between yield under stress and anthocyanins content and number of stomata was nonsignificant. Correlations between other estimated attributes are also illustrated in Table (6).

\section{DISCUSSION}

Water stress decreased seed yield, and this was accompanied with a reduced biomass, RGR, NAR, RWC, and MSI (Tables 2 and 3). RGR of soybean plants was reported to decrease in response to waterstress (Stolf-Moreira et al., 2010). Yield of various soybean cultivars was reduced in response to drought stress (Kobraee et al., 2011; Masoumi et al., 2011; Sadeghipour and Abbasi, 2012; Abdel-Mohsen et al., 2013). In addition, drought stress reduced dry matter accumulation in plant organs as well as shoot tissue moisture content whereas increased electrolyte leakage in various soybean genotypes (Tint et al., 2011). Reduced NAR in response to drought may be due to drought-induced ABA levels in the leaves which decreases stomatal conductance hence reducing net photosynthesis (Mutava et al., 2015). Stolf-Moreira et al. (2010) reported a reduction in photosynthetic rate coupled with a reduction in stomatal conductance in two soybean cultivars 30 days after the onset of water stress. Drought stress can also limit photosynthesis by reducing the activity of ribulose 1,5-bisphosphate carboxylase, thereby damaging the biochemical $\mathrm{CO}_{2}$-fixation machinery (Machado-Filho et al., 2006). Yield loss under drought conditions may be due to droughtinduced flower abscission (Daneshian and Zare, 2005).

Results of the present study indicated that membrane stability index was decreased in all genotypes in response to drought stress, and the index in case of cv G 111 was significantly higher than those in cvs G 22 and G 35. Vasquez-Tello et al. (1990) concluded that maintenance of membrane integrity after water stress is an important strategy for drought resistance. In addition, membranes stability and integrity under water stress conditions is a major indicator of drought tolerance in plants (Tint et al., 2011). Drought-induced decrease in MSI is due to an increase in the rate of generation of ROS which induce lipid peroxidation in the membrane structures of the cells (Kabiri et al., 2014).

The preset investigation results show that STI differed significantly between studied cultivars demarcating between high- and low- yielding cultivars under drought stress. Though different stress tolerance indices could be used to assess the performance of the genotype under stress conditions (Tint et al., 2011), STI is widely advocated to distinguish better yielding genotypes under drought stress (Sanjari and Yazdansepas, 2008). Kargar et al. (2014) classified apopulation of 14 soybean genotypes to either droughttolerant or drought-susceptible based on STI. In addition, STI showed a consistent correlation with yield in seasonal variations (Golabadi et al., 2006) and locations (Pourdad, 2008).

Results of the present investigation revealed that drought stress increased phenols and flavonoids content in cv Giza 111 as well as anthocyanins and proline contents in all cultivars. In line with the results of the present investigation, total flavonoids and anthocyanins 
content was increased in response to drought stress (Baroowa and Gogoi, 2012; 2015). Flavonoids and anthocyanins are important low molecular weight antioxidant compounds in plants (Radyuk et al., 2009) which play an important role in stress defense (Chu et al., 2010). Flavonoids act as free radical scavangers (Chutipaijit et al., 2008). Elevated anthocyanins level enhances resistance to water loss as the glycosides attached to anthocyanins in vacuoles adjust the osmotic potential of the cells, thereby minimizing water loss through evapotranspiration (Chutipaijit et al., 2008). In addition, Peng et al.( 2006) suggested that anthocyanins may be a beneficial primary antioxidant in rice leaves against oxidative stress induced by environmental stresses.

Table (2). Seed yield; stress tolerance index (STI) based on yield, biomass, relative growth rate (RGR) and net assimilation rate (NAR) of soybean cultivars under either normal (cont) or water stress (WS) conditions (average of the two growing seasons).

\begin{tabular}{|c|c|c|c|c|c|c|c|c|c|c|c|c|}
\hline \multirow{2}{*}{ Characters } & \multicolumn{2}{|c|}{ Seed yield g plant ${ }^{-1}$} & \multirow{2}{*}{ STI } & \multicolumn{3}{|c|}{ Biomass g plant ${ }^{-1}$} & \multicolumn{3}{|c|}{$\operatorname{RGR}\left(\mathrm{mg} \mathrm{g}^{-1} \mathbf{d}^{-1}\right)$} & \multicolumn{3}{|c|}{$\operatorname{NAR}\left(\mathrm{mg} \mathrm{cm}^{2} \mathrm{~d}^{-1}\right)$} \\
\hline & Cont & WS & & Cont & WS & WS/cont & ont. & WS & WS/c & Cont. & WS & WS/cont \\
\hline G22 & $16.2^{\mathrm{a}^{*}} \mathrm{~A}^{* *}$ & $7.7^{\mathrm{b}}$ & $0.56^{\mathrm{ab}}$ & $24.0_{\mathrm{A}}^{\mathrm{a}}$ & $14.6^{\mathrm{ab}}{ }_{\mathrm{B}}$ & 0.48 & $20.2^{\mathrm{a}} \mathrm{A}$ & $11.5^{\mathrm{ab}}{ }_{\mathrm{B}}$ & 0.57 & $0.90_{\mathrm{A}}^{\mathrm{a}}$ & $0.67^{\mathrm{ab}}{ }_{\mathrm{B}}$ & 0.74 \\
\hline 335 & & $6.8^{c}{ }_{B}$ & $0.42^{\mathrm{c}}$ & $23.2^{\mathrm{a}} \mathrm{A}$ & $9.0_{\mathrm{B}}^{\mathrm{b}}$ & 0.39 & $20.0^{\mathrm{a}}{ }_{\mathrm{A}}$ & $10.7^{\mathrm{b}}$ & 0.53 & $0.85_{\mathrm{A}}^{\mathrm{a}}$ & $0.61^{\mathrm{b}}{ }_{\mathrm{B}}$ & 0.71 \\
\hline G111 & $14.6^{\mathrm{ab}}$ & $9.2^{\mathrm{a}} \mathrm{B}$ & $0.61^{\mathrm{a}}$ & $21.8_{\mathrm{A}}^{\mathrm{a}}$ & $15.3^{\mathrm{a}}{ }_{\mathrm{B}}$ & 0.70 & $19.6_{\mathrm{A}}^{\mathrm{a}}$ & $12.8^{\mathrm{a}}{ }_{\mathrm{B}}$ & 0.65 & $0.84_{\mathrm{A}}^{\mathrm{a}}$ & $0.70_{\mathrm{A}}^{\mathrm{a}}$ & 0.83 \\
\hline
\end{tabular}

* Different small letters within the same column indicate significant differences between means at P $\leq 0.05$ according to DMRT.

** Different capital letters within the same row indicate significant difference between cont and WS treatments at P $\leq 0.05$ according to DMRT.

Table (3). Relative water content (RWC), membrane stability index (MSI), phenols, flavonoids, anthacyanins and proline contents in leaves of soybean cultivars under either normal (cont) or water stress (WS) conditions (average of the two growing seasons).

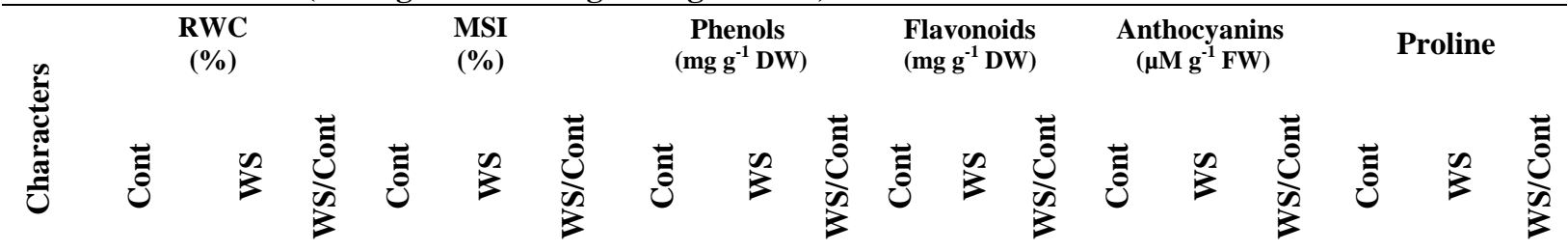

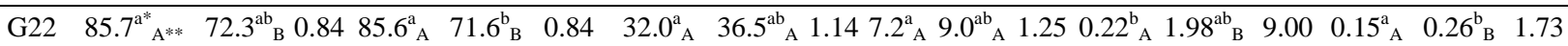
$\begin{array}{llllllllllllllllllllllllllll}\mathrm{G} 35 & 86.2^{\mathrm{a}}{ }_{\mathrm{A}} & 68.7^{\mathrm{b}}{ }_{\mathrm{B}} & 0.80 & 86.0^{\mathrm{a}}{ }_{\mathrm{A}} & 70.2^{\mathrm{b}}{ }_{\mathrm{B}} & 0.82 & 30.7^{\mathrm{a}}{ }_{\mathrm{A}} & 34.6^{\mathrm{b}}{ }_{\mathrm{A}} & 1.13 & 7.5^{\mathrm{a}}{ }_{\mathrm{A}} & 8.6^{\mathrm{b}}{ }_{\mathrm{A}} & 1.15 & 0.26^{\mathrm{a}}{ }_{\mathrm{A}} & 1.86^{\mathrm{b}}{ }_{\mathrm{B}} & 7.15 & 0.17^{\mathrm{a}}{ }_{\mathrm{A}} & 0.24^{\mathrm{b}}{ }_{\mathrm{B}} & 1.41\end{array}$

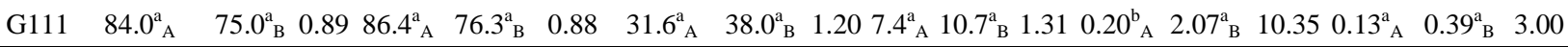
* Different small letters within the same column indicate significant differences between means at P $\leq 0.05$ according to $D M R T$.

** Different capital letters within the same row indicate significant difference between cont and WS treatments at $\mathrm{P} \leq 0.05$ according to DMRT.

Table (4). Stomata and hair density (number $\mathrm{mm}^{-2}$ ) on the abaxial and adaxial surface of the leaves of control (cont) and water-stressed (WS) soybean cultivars (average of the two growing seasons).

\begin{tabular}{|c|c|c|c|c|c|c|c|c|c|c|c|c|}
\hline \multirow{3}{*}{ Cultivars } & \multicolumn{6}{|c|}{ Stomata (Number $\mathrm{mm}^{-2}$ ) } & \multicolumn{6}{|c|}{ Hairs (Number $\mathrm{mm}^{-2}$ ) } \\
\hline & \multicolumn{3}{|c|}{ Abaxial } & \multicolumn{3}{|c|}{ Adaxial } & \multicolumn{3}{|c|}{ Abaxial } & \multicolumn{3}{|c|}{ Adaxial } \\
\hline & Cont & WS & WS/cont & Cont & WS & WS/cont & Cont & WS & WS/cont & Cont & WS & WS/cont \\
\hline $\mathrm{G} 22$ & $95.7^{\mathrm{a}^{*}} \mathrm{~A}^{* *}$ & $86.6^{\mathrm{a}}$ & 0.90 & $39.6^{\mathrm{a}}$ & $28.7^{\mathrm{a}}{ }_{\mathrm{B}}$ & 0.72 & $10.0_{\mathrm{A}}^{\mathrm{a}}$ & $36.3^{\mathrm{ab}}{ }_{\mathrm{B}}$ & 3.6 & $18.0_{\mathrm{A}}^{\mathrm{a}}$ & $25.7^{\mathrm{c}}{ }_{\mathrm{B}}$ & 1.4 \\
\hline G35 & $96.0^{\mathrm{a}}{ }_{\mathrm{A}}$ & $84.0^{\mathrm{a}}$ & 0.88 & $40.4_{\mathrm{A}}^{\mathrm{a}}$ & $26.0^{\mathrm{ab}}{ }_{\mathrm{B}}$ & 0.64 & $11.2^{\mathrm{a}} \mathrm{A}$ & $30.0^{\mathrm{b}}$ & 2.7 & $17.8^{\mathrm{a}}{ }_{\mathrm{A}}$ & $32.3^{\mathrm{b}}{ }_{\mathrm{B}}$ & 1.8 \\
\hline G111 & $94.0_{\mathrm{A}}^{\mathrm{a}}$ & $92.4_{\mathrm{A}}^{\mathrm{a}}$ & 0.98 & $37.0^{\mathrm{a}}{ }_{\mathrm{A}}$ & $22.8_{\mathrm{B}}^{\mathrm{b}}$ & 0.62 & $9.8_{\mathrm{A}}^{\mathrm{a}}$ & $42.6^{\mathrm{a}}{ }_{\mathrm{B}}$ & 4.3 & $15.0_{\mathrm{A}}^{\mathrm{a}}$ & $38.6_{\mathrm{B}}^{\mathrm{a}}$ & 2.6 \\
\hline
\end{tabular}

* Different small letters within the same column indicate significant differences between means at P $\leq 0.05$ according to $D M R T$.

** Different capital letters within the same row indicate significant difference between cont and WS treatment at $\mathrm{P} \leq 0.05$ according to DMRT.

Table (5). Areoles frequency and dimensions as well as calcium oxalate crystals number and dimensions in the leaves of control (cont) and water-stressed (WS) soybean cultivars (average of the two growing seasons).

\begin{tabular}{|c|c|c|c|c|c|c|c|c|c|c|c|c|}
\hline \multirow{2}{*}{ Cultivars } & \multicolumn{3}{|c|}{$\begin{array}{c}\text { Areoles } \\
\left(\text { Number } \mathbf{~ m m}^{-2}\right)\end{array}$} & \multicolumn{3}{|c|}{$\begin{array}{l}\text { Areoles dimensions } \\
\text { (Length } X \text { width, } \mu \text { ) }\end{array}$} & \multicolumn{3}{|c|}{$\begin{array}{c}\text { Crystals } \\
\left(\text { Number } \mathbf{~ m m}^{-2}\right)\end{array}$} & \multicolumn{3}{|c|}{$\begin{array}{l}\text { Crystals dimensions } \\
\text { (Length } \mathrm{X} \text { width, } \boldsymbol{\mu})\end{array}$} \\
\hline & Cot & WS & & Cont & WS & & t & 5 & & Cot & WS & $\begin{array}{l}\text { WS/ } \\
\text { cont }\end{array}$ \\
\hline $\mathrm{G} 22$ & $1.4 \mathrm{~A}^{* *}$ & . & 1.45 & $30 \times 106^{\circ}{ }_{A}$ & 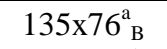 & 0.54 & $170^{\mathrm{ab}}$ & $217^{\mathrm{ab}}$ & 1.27 & $7.3 \times 4.6_{\mathrm{A}}^{\mathrm{a}}$ & $18.3 \times 8$ & .7 \\
\hline 35 & $18.8^{\mathrm{b}}{ }_{\mathrm{A}}$ & $26.8^{\mathrm{b}}{ }_{\mathrm{A}}$ & 1.42 & $206 \times 135^{\mathrm{a}}{ }_{\mathrm{A}}$ & $184 \times 107^{\mathrm{ab}} \mathrm{A}$ & 0.71 & $192^{\mathrm{a}}{ }_{\mathrm{A}}$ & $243^{\mathrm{b}}{ }_{\mathrm{B}}$ & 1.26 & $8.2 \times 5.3^{\mathrm{a}}{ }_{\mathrm{A}}$ & $15.6 \times 7.2^{\mathrm{b}}{ }_{\mathrm{B}}$ & 2.6 \\
\hline G111 & $22.5_{\mathrm{A}}^{\mathrm{a}}$ & $36.4^{\mathrm{a}}{ }_{\mathrm{B}}$ & 1.6 & $165 \times 96_{\mathrm{A}}^{\mathrm{a}}$ & $97 \times 62^{b}{ }_{B}$ & 0.38 & $155^{\mathrm{b}}{ }_{\mathrm{A}}$ & $280^{\mathrm{a}}{ }_{\mathrm{B}}$ & 1.80 & $7.6 \times 4.0^{\mathrm{a}}{ }_{\mathrm{A}}$ & $19.8 \times 9.7^{\mathrm{a}}$ & 6.3 \\
\hline
\end{tabular}

* Different small letters within the same column indicate significant differences between means at P $\leq 0.05$ according to $D M R T$.

** Different capital letters within the same row indicate significant difference between cont and WS treatment at $\mathbf{P} \leq 0.05$ according to DMRT. 
Table (6). Correlation coefficients between recorded parameters and seed yield of soybean cultivars under water-stress condition.

\begin{tabular}{|c|c|c|c|c|c|c|c|c|c|c|c|}
\hline & DBM & RGR & NAR & RWC & MSI & $\mathbf{P C}$ & FC & $\mathbf{A C}$ & PrC & SN & HN \\
\hline Stress Yield & $0.79 * *$ & $0.72 * *$ & $0.64 * *$ & $0.81^{* *}$ & $0.69 *$ & $0.60 *$ & $0.56^{*}$ & $0.42^{\mathrm{ns}}$ & $0.63^{*}$ & $0.36^{\mathrm{ns}}$ & $0.64 *$ \\
\hline $\begin{array}{l}\text { Dry biomass } \\
(\mathrm{DBM})\end{array}$ & & $0.63 *$ & $0.60 *$ & $0.75^{* *}$ & $0.62 *$ & $-0.36^{\text {ns }}$ & $-0.14^{\mathrm{ns}}$ & $-0.26^{\mathrm{ns}}$ & $0.26^{\mathrm{ns}}$ & $0.28^{\mathrm{ns}}$ & $-0.23^{\mathrm{ns}}$ \\
\hline $\begin{array}{l}\text { Relative growth rate } \\
\text { (RGR) }\end{array}$ & & & $0.54 *$ & $0.68 *$ & $0.58 *$ & $-0.28^{\mathrm{ns}}$ & $-0.19^{\mathrm{ns}}$ & $-0.22^{\mathrm{ns}}$ & $0.24^{\mathrm{ns}}$ & $0.26^{\mathrm{ns}}$ & $-0.26^{\mathrm{ns}}$ \\
\hline $\begin{array}{l}\text { Net assimilation rate } \\
\text { (NAR) }\end{array}$ & & & & $0.71 * *$ & $0.62 *$ & $-0.35^{\mathrm{ns}}$ & $-0.40^{\mathrm{ns}}$ & $-0.28^{\mathrm{ns}}$ & $0.31^{\mathrm{ns}}$ & $0.65^{*}$ & $-0.70 * *$ \\
\hline $\begin{array}{l}\text { Relative water } \\
\text { content (RWC) }\end{array}$ & & & & & $0.69 *$ & $0.36^{\mathrm{ns}}$ & $0.40^{\mathrm{ns}}$ & $0.43^{\mathrm{ns}}$ & $0.30^{\mathrm{ns}}$ & $-0.57 *$ & $-0.62 *$ \\
\hline $\begin{array}{l}\text { Membrane stability } \\
\text { index (MSI) }\end{array}$ & & & & & & $0.56^{*}$ & $0.63^{*}$ & $0.27^{\mathrm{ns}}$ & $0.70 * *$ & $0.30^{\mathrm{ns}}$ & $0.21^{\mathrm{ns}}$ \\
\hline $\begin{array}{l}\text { Phenols content } \\
\text { (PC) }\end{array}$ & & & & & & & $0.57 *$ & $0.17^{\mathrm{ns}}$ & $0.19^{\mathrm{ns}}$ & $0.26^{\mathrm{ns}}$ & $0.13^{\mathrm{ns}}$ \\
\hline $\begin{array}{l}\text { Flavanoids content } \\
\text { (FC) }\end{array}$ & & & & & & & & $0.28^{\mathrm{ns}}$ & $0.19^{\mathrm{ns}+}$ & $0.36^{\mathrm{ns}}$ & $0.24^{\mathrm{ns}}$ \\
\hline $\begin{array}{l}\text { Anthocyanins } \\
\text { content (AC) }\end{array}$ & & & & & & & & & $0.36^{\mathrm{ns}}$ & $0.41^{\mathrm{ns}}$ & $-0.56^{*}$ \\
\hline $\begin{array}{l}\text { Proline content } \\
(\operatorname{PrC})\end{array}$ & & & & & & & & & & $0.36^{\mathrm{ns}}$ & $0.23^{\mathrm{ns}}$ \\
\hline $\begin{array}{l}\text { Stomata number } \\
\text { (SN) } \\
\text { Hairs number } \\
(\mathrm{HN})\end{array}$ & & & & & & & & & & & $-0.54 *$ \\
\hline
\end{tabular}

Results of previous studies indicated that drought stress increased proline accumulation (Quilambo, 2004; Baroowa and Gogoi, 2015). Proline has been assigned an important role in adaptation of plants to stress conditions due to its diverse biological effects such as osmotic regulation, antioxidant action, energy transfer as well as carbon and nitrogen source (Kuznetsov and Shevyakova, 1999).

A decrease in stomata number/unit leaf area on the adaxial surface and an increase in hairs density on both leaf surfaces in response to drought stress were detected in the present study (Table 4). The density of trichomes on leaf surface reflects the adaptive responses of soybean plants to environmental conditions ( $\mathrm{Du}$ et al., 2009). Stress resulting from irradiation increased trichomes number per leaf surface area on both abaxial and adaxial surface of soybean leaves (Celik et al., 2014). Increased pubescence in response to drought was also reported (Abrams, 1994;Karabourniotis and Bornman, 1999; Picotte et al., 2008). Enhanced Pubescence hinders the outward loss of water by transpiration by reducing incident radiation on blade surface hence, decreasing leaf temperature and maintaining a thin layer of stagnant air adjacent to the leaf surface, providing an advantage to plants growing in water-deprived environments. In this regards, it is worth mentioning that increasing trichome density have been shown to increase water use efficiency under water stress conditions (Picotte et al., 2008). Stress-induced trichome formation was correlated with induction of the expression of TTG1 and GL2 genes that regulate trichome development (Celik et al., 2014).
Inconsistent results regarding the effect of stress on stomata number were reported. While a decrease was reported in response to irradiation with gamma rays (Celik et al., 2014), no effect of abiotic stress treatments on stomatal density was reported (Rodiyati et al., 2004; Inamullah and Isoda, 2005). These inconsistences could be explained by the variability in leaf position and plant developmental stage. In the current study, water stress decreased density of stomata on the adaxial epidermis in all cultivars. Decreasing stomatal density may be a defense response of plants to avoid drought-induced dehydration by minimizing water loss. One approach to minimize water loss is regulating stomatal density and dimensions (Mehri et al., 2009).

According to the results of the present study, drought stress increased number of areoles/ unit leaf blade whereas decreased areole size, implying droughtinduced development of extensive veinlets. This effect is advantageous to water-stressed plants as higher venation density provides more channels for water conduction. Drought-tolerant genotypes of Coffea arabica which demonstrate better yield performance in marginal areas were characterized by smaller areole area compared with drought-susceptible genotypes (Mishra et al., 2011). They concluded that venation patterns could be used for screening cultivars in breeding programs for drought tolerance. Calcium oxalate is a very common and widespread mineral that have several biological roles in plants. Crystals in the epidermis may reflect sunlight and impede transmission of sunlight to the underlying tissues (Fahn and Cutler, 1992) thus, cooling the leaf tissues (Franceschi, 2001) 


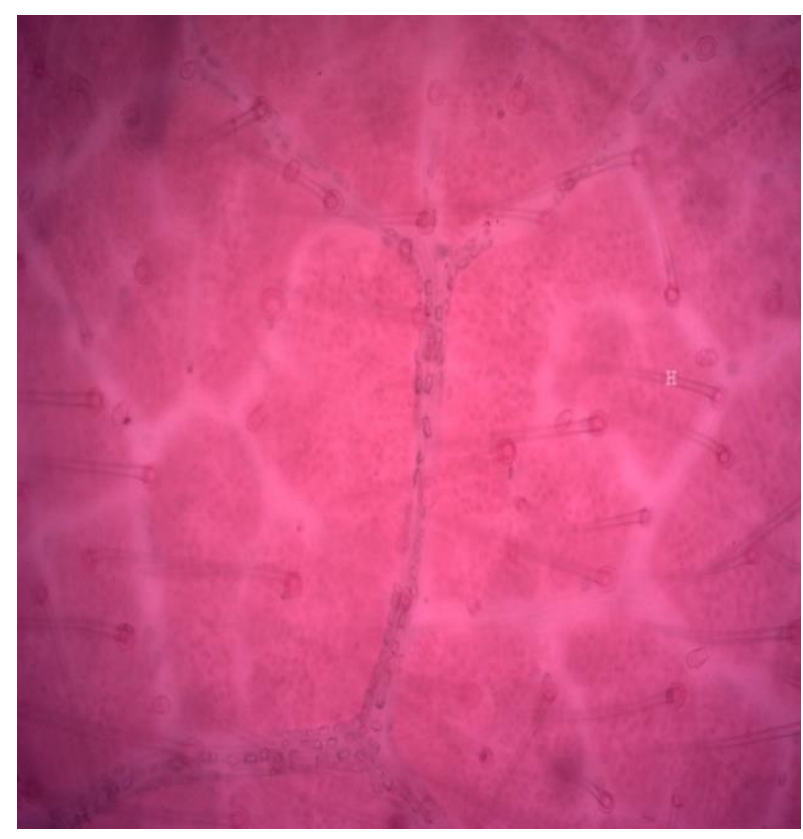

(a)

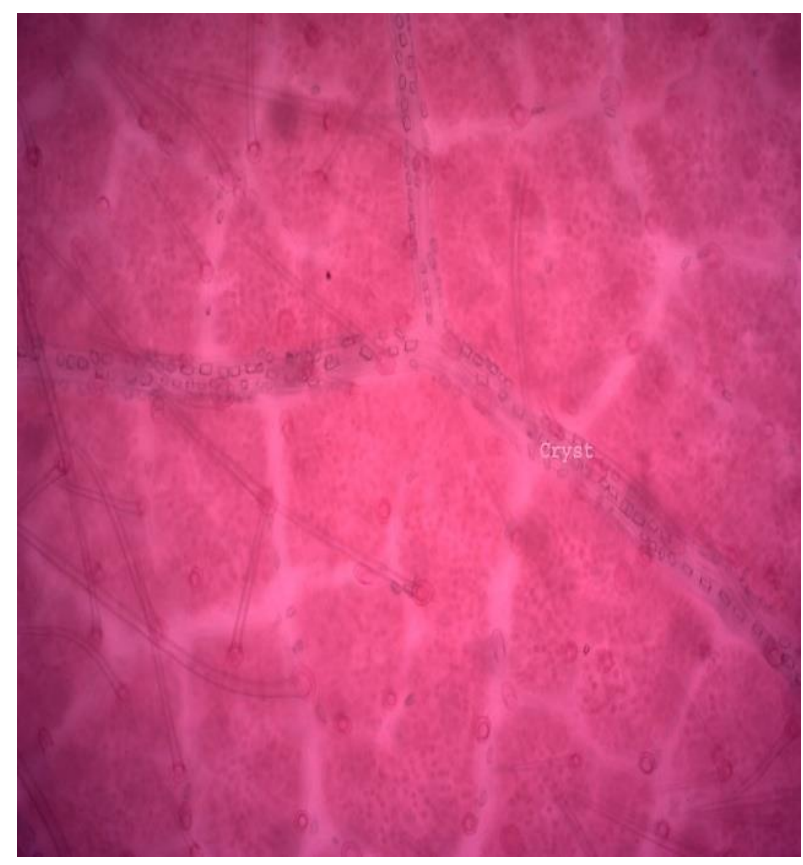

(c)

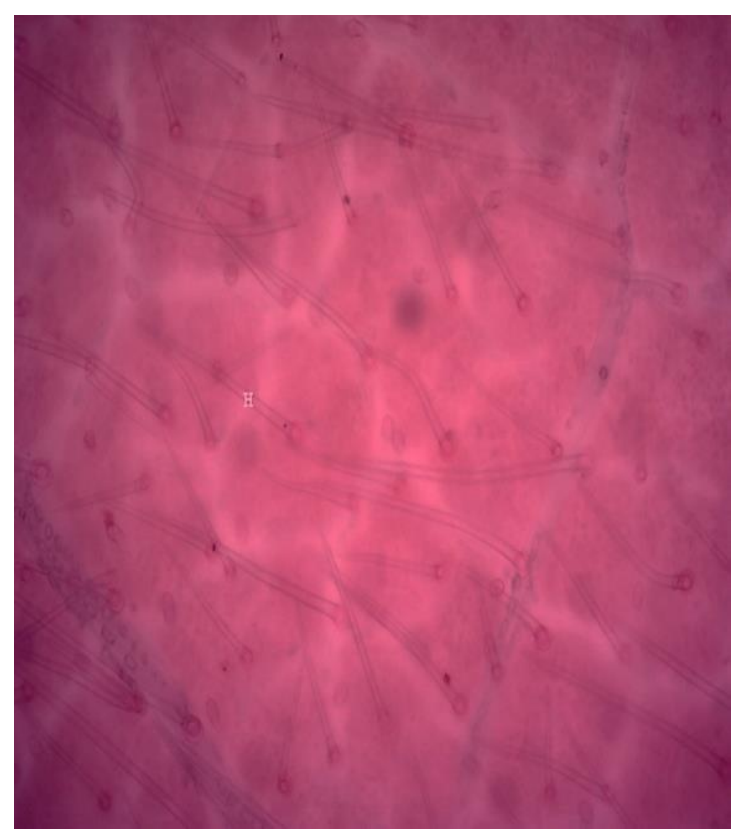

(b)

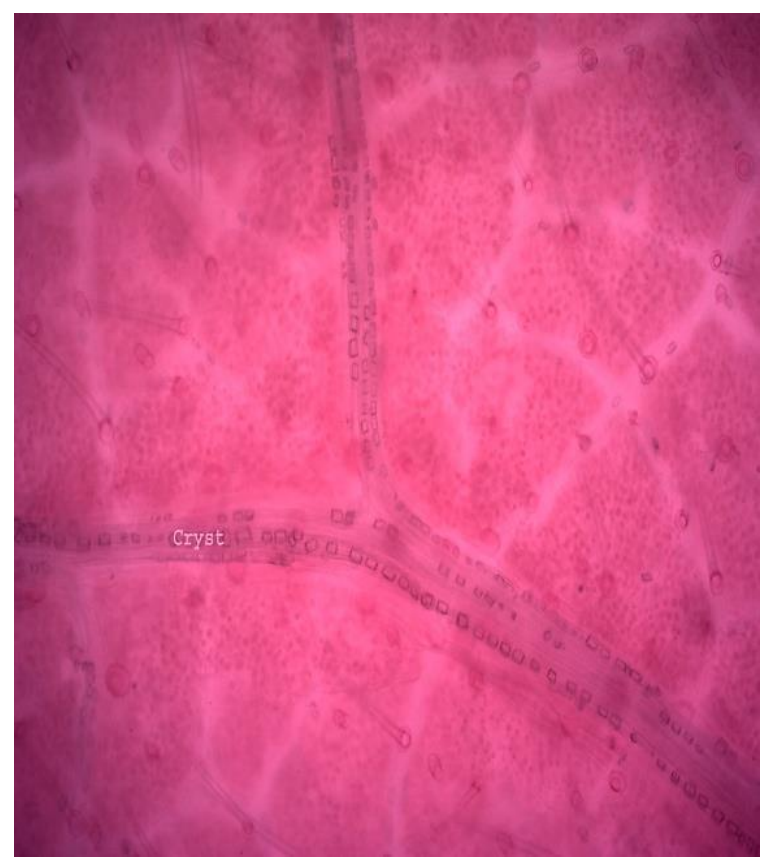

(d)

Fig (1): Hairs (a, b) and crystals (c, d) in the adaxial epidermis of cv Giza 111 as affected by drought stress (b, d) compared with control (a, c); $\mathbf{x} 40$.

Results of the preset study indicated a significant positive correlation between seed yield under stress and dry biomass, RGR, NAR, RWC, MSI, phenols, flavonoids, proline and hairs density. In line with these results, shoot biomass accumulation in beans was positively and significantly correlated with seed yield not only under drought stress but also under wellwatered conditions (Shenkut and Brick, 2003). Shoot biomass is therefore indicative of seed yield hence, could be an important trait in the selection of soybean germplasm for drought tolerance. Several morphological and physiological traits positively correlated with seed yield under stress have been identified (Masoumi et al., 2011; Tint et al., 2011; Maleki et al., 2013). Shoot dry matter, stem moisture content and electrolyte leakage showed significant correlation with stress yield (Tint et al., 2011). Masoumi et al. (2011) recorded significant positive correlations between stress yield and different components of the plant's enzymatic antioxidant defense system.A corresponding correlation was recorded in the present investigation between other components of the plant's antioxidant system i.e. phenols and flavonoids, indicating the vitality of an efficient antioxidant system in plants' drought tolerance. The present study results revealed a positive significant correlation between MSI 
and RWC. Similar results were reported by Tint et al. (2011) who concluded that better membrane integrity under stress conditions help to stabilize moisture in plant tissues that may help in maintaining stomatal conductance and osmotic potential, which improve water use efficiency (Franca et al., 2000).

\section{CONCLUSIONS}

Based on the results of the present investigation, it could be concluded that cv Giza 111 is better adapted to drought-affected areas and could be utilized in breeding programs for drought tolerance. Better drought tolerance of cv Giza 111 was based on acquision of the highest stress tolerance index based on stress yield, which was positively and significantly correlated with dry biomass, RGR, NAR, RWC, MSI, phenols, flavonoids and proline contents as well as hairs number per leaf surface area. Combining these traits in breeding programs should increase drought tolerance in soybean.

\section{REFERENCES}

Abd El-Mohsen, A.A.; G.O. Mahmoud and S.A. Safina, (2013). Agronomical evaluation of six soybean cultivars using correlation and regression analysis under different irrigation regime conditions. J. Plant Breeding and crop Sci., 5: 91-102.

Abrams, M.P. (1994). Genotypic and phenotypic variation as stress adaptations in temperate tree species: a review of several case studies. Tree Physiol., 14: 833-842.

Adejare, E.B. and C.E. Umebese (2008). Water stress induces cultivar dependent changes in stomatal complex, yield and osmotic adjustments in Glycine max L. Intern. J. of Agric. Res., 3: 287-295.

Baroowa, B. and N. Gogoi (2012). Effect of induced drought on different growth and biochemical attributes of black gram (Vigna mungo L.) and green gram (Vigna radiata L.). J. Environ. Res. Develop., 6: 584-593.

Baroowa, B. and N. Gogoi (2015). Changes in plant water status, biochemical attributes and seed quality of black gram and green gram genotypes under drought. Intern.Lett. Nat. Sci., 42: 1-12.

Bates L.S.; R.P. Waldren and I.D. Tear (1973). Rapid determination of free proline for water stress studies. Plant Soil 39: 205-207.

Bray, G.A.; J. Bailey-Serres and E.Weretilnyk (2000). Responses to abiotic stresses. In: G.B. Gruissem and R. Jones (Eds., Biochemistry and Molecular Biology of Plants. American Society of Plant Physiologists, Rockville, M.D.

Celik, O.; C. Atak and Z. Suludere (2014). Response of soybean plants to gamma radiation: Biochemical analyses and expression patterns of trichome development. Plant Omics J., 7: 382-391.

Chu J.; X . Yao and Z. Zhang (2010). Responses of wheat seedlings to exogenous selenium supply under cold stress. Biol Trace Elem Res, 136: 355-363.
Chutipaijit, S.; S. Chaum and K. Sompompailin (2008). Influence of drought stress on proline and anthocyanin accumulation in indica rice cultivars. KMITL Sci. J., 8: 40-47.

Cobraee, S. and K. Shamsi (2011). Effect of irrigation regimes on quantitative traits of soybean (Glycine max.L.). Asian J. Exp. Biol. Sci., 2: 441-448.

Daneshian, J. and D. Zare (2005). Diversity for resistance drought on soybean J. Agric. Sci., 1: 23-50.

Du, W-J.; D.-Y. Yu and S.-X. Fu (2009). Analysis of QTLs for the Trichome Density on the Upper and Lower Surface of Leaf Blade in Soybean [Glycine $\max$ (L.) Merr.] Agric. Sci. China,8: 529-537.

Fahn, A. and D.F. Cutler (1992). Xerophytes. Gebruder, Borntraeger, Berlin.

Fernandez, G.C.J. (1992). Effective selection criteria for assessing plant stress tolerance. In C.G. Kuo (Ed.), Adaptation of food crops to temperature and water stress. Proc. Int. Symp., Taiepi, Taiwan, 13-18 Aug., 1992. Asian Veg. Res. Dev. Center, Shanhua, Taiwan.

Franca, M.G.C.; A.T.P. Thi; C. Pimentel; R.O.P. Rossiello; Y.Z. Fodil and D. Laffray (2000). Differences in growth and water relations among Phaseolus vulgaris cultivars in response to induced drought stress. Environ. Exp. Bot., 43: 227-237.

Franceschi, V. (2001). Calcium oxalate in plants. Trends in Plant Science, 6: 331.

Frederick, J.R.; C.R. Camp, and P.J. Bauer (2001). Drought-stress effects on branch and main stem seed yield and yield components of determinate soybean. Crop Sci., 41: 759-763.

Gao, X.; L. Björk; V. Trajkovski and M. Uggla (2000). Evaluation of antioxidant activities of rosehip ethanol extracts in different test systems. J. Agric. Food Chem., 80:2021-2027.

Golabadi, M.; A. Arzani, and H. Mirom (2006). Assessment of drought tolerance in segregation populations in durum wheat. Afr. J. Agric. Res., 1: $162-171$.

Gonzalez, L. and M. Gonzalez - Vilar (2001). Determination of relative water content. In: REIGOSA, M. J. Handbook of Plant Ecophysiology Techniques. Dordrecht: Kluwer Academic. p. 207-212.

Hamayun, M.; S.A. Khan; Z.K. Shinwari; A.L. Khan; N. Ahmad, and I.-J. Lee (2010). Effect of polyethylene glycol induced drought stress on physio-hormonal attribues of soybean. Pak. J. Bot., 42: 977-986.

Hickey, L.J. (1973). Classification of the architecture of the dicotyledonous leaves. Amer. J. Bot., 60: 17-33.

Hoddinott, K.B. and R.O. Lamb (1990). PhysicoChemical Aspects of Soil and Related Materials. ASTM (ASTM special technical publication; 1095) Philadelphia, PA. 
Inamullah, A. and A. Isoda (2005). Adaptive responses of soybean and cotton to water stress.1. Transcription changes in relation to stomatal area and stomatal conductance. Plant Prod. Sci., 8: 16-26.

Jordan, B.R.; P.E. James; A. Strid and R.G. Anthony (1994). The effect of ultraviolet-B radiation on gene expression and pigment composition in etiolated and green pea leaf tissue: UV-B induced changes are gene-specific and dependent upon the development stage.Plant Cell Environ.,17: 45-54.

Kabiri, R.; F. Nasibi and H. Farahbakhsh (2014). Effect of exogenous salicylic acid on some physiological parameters and alleviation of drought stress in Nigella sativa Plant under hydroponic culture. Plant Protect. Sci., 50: 43-51.

Karabourniotis, G. and J. Bornman (1999). Penetration of UV-A, UV-B and blue light through the leaf trichome layers of two xeromorphic plants, olive and oak, measured by optical fibre micropropes. Physiol. Plant., 105: 655-661.

Kargar, S.M.A.; A. Mostafaie; E.M. Hervan and S.S. Ourdad, (2014). Evaluation of soybean genotypes using drought stress tolerant indices. Inter. J. Agron. Agric. Res., 5: 103-113.

Kuznetsov, V. and N. Shevyakova (1999). Proline under stress: biological role, metabolism and regulation. Russ. J. Plant Physiol., 46: 274-286.

Machado-Filho, J.A.; E. Campostrini; O.K. Yamanishi, and G.R. Fagundes (2006). Seasonal variation of leaf gas exchange in papaya plants grown under field condition. Bragantia, 65: 185-196.

Maleki, A.; A. Naderi; R. Naseri; A. Fathin; S. Bahamin and R. Maleki (2013). Physiological performance of soybean cultivars under drought stress. Bull. Env. Pharmacol. Life Sci., 2: 38-44.

Masoumi, H.; F. Darvish; J. Daneshian; G. Ormohammadi, and D. Habibi (2011). Effects of water deficit stress on seed yield and antioxidants content in soybean (Glycine $\max$ L.) cultivars. African J. Agric. Res., 6: 1209-1218.

Mehri, N.; R. Fotovat; J. Saba and F. Jabbari (2009). Variation of stomata dimensions and densities in tolerant and susceptible wheat cultivars under drought stress.J. Food Agric. Environ.,7:167-170.

Mishra , M.K.; P. Dandamudi; S.P. Nayani; S.S. Munikoti; and S.S. Chelukunda (2011). Variability in stomatal features and leaf venation pattern in Indian coffee (Coffea arabica L.) cultivars and their functional significance. Botanica Serbica, 35: 111-119.

Mutava, R.N.; S.J.K. Prince; N.H. Syed; L. Song; B. Valliyodan; W. Chen and H.T. Nguyen (2015). Understanding abiotic stress tolerance mechanisms in soybean: A cooperative evaluation of soybean response to drought and flooding stress. Plant Physiol. Biochem., 86: 109120.

Peng C.L.; Z.F. Lin; G.Z. Lin and S.W. Chen (2006). Antioxidant functions of purple rice with abundant anthocyanin. Sci China Ser. C, 36:209-216.
Picotte, J.J.; D.M. Rosenthal; J.M. Rhode and M.B. Cruzan (2007). Plastic responses to temporal variation in moisture availability: consequences for water use efficiency and plant performance. Oecologia, 153: 821-832.

Picotte, J.J.; J.M. Rhode and M.B. Cruzan (2008). Leaf morphological responses to variation in water availability for plants in the Piriqueta caroliniana complex. Plant Ecol., DOI 10.1007/s11258-008-9451-9.

Pourdad, S.S. (2008). Study on drought resistance indices in spring safflower. Acta Agron. Hung., 56: 203-212.

Quilambo, O.A. (2004). Proline content, water retention capability and cell membrane integrity as parameters for drought tolerance in two peanut cultivars. South African J. Bot., 70: 227-234.

Radford ,P.G. (1967). Growth Analysis Formulae Their Use and Abuse. Crop Sci; 3: 171-175.

Radiyati, A.; E. Arisoesilaningsih; Y. Isagi and N. Nakagoshi, (2004).Responses of Cyperus brevifolivs (Rottb.) Hassk. and Cyperus kyllingia Endl. to varying soil water availability. Environ. Exp. Bot., 53: 259-269.

Radyuk, M.S.; I.N. Domanskaya; R.A. Shcherbakov and N.V. Shalygo (2009). Effect of low abovezero temperature on the content of low-molecular antioxidants and activities of antioxidant enzymes in green barley leaves. Russ. J. Plant Physiol., 56: 175-180.

Sadeghipour, O. and S. Abbass (2012). Soybean response to drought and seed inoculation. World Appl. Sci. J., 17: 55-60.

Sanjari, P.A. and A. Yazdansepas (2008). Evaluation of wheat (Triticum aestivum L.) genotypes under pre- and post-anthesis drought stress condition. J. Agric. Sci. Tech., 10: 109-121.

Serraj, R. and T.R. Sindair (1998). Soybean cultivar variability for nodule formation and growth under drought. Plant and soil, 202: 159-166.

Shenkut, A.A. and M.A. Brick (2003). Traits associated with dry edible bean (Phaseolus vulgaris L.) productivity under diverse soil moisture environments. Euphytica, 133: 339-347.

Stolf-Moreira, R.; M.E. Medri; N. Neumaier; N.G. Lemos; J.A. Pimenta; S. Tobita, et al., (2010). Soybean physiology and gene expression during drought. Genet. Mol. Res., 9: 1946-1956.

Tint, A.M.M.; E. Sarobol; S. Nakasathein and W. Chaiaree (2011). Differential responses of selected soybean cultivars to drought stress and their drought tolerant attributions. Kasetsart J. (Nat. Sci.), 45: 571-582.

Vasquez-Tello, A.; Y. Zuily-Fodil,; A.T.P. Thi, and J.B.V. Da Silva (1990). Electrolyte leakage and soluble sugar content as physiological tests for screening for resistance to water stress in Phaseolus and Vigna species. J. Exp. Bot., 41: 827-832.

Weyers, J. D. B. and A. J. Travis (1981). Selection and preparation of leaf epidermis for experiments on stomatal physiology. J. Exp. Bot., 32: 837-850. 
الصفات المرتبطة بتفاوت القدرة على تحمل الإجهاد فى بعض أصناف فول الصويا

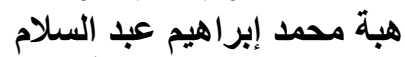

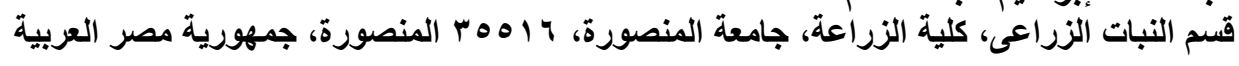

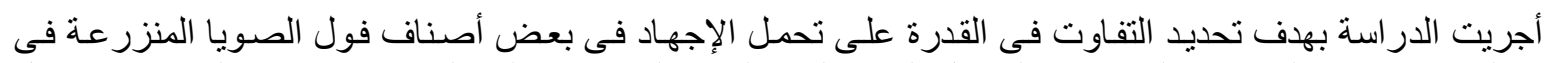

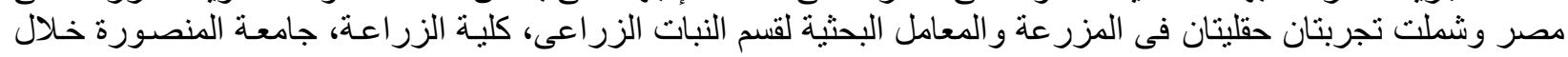

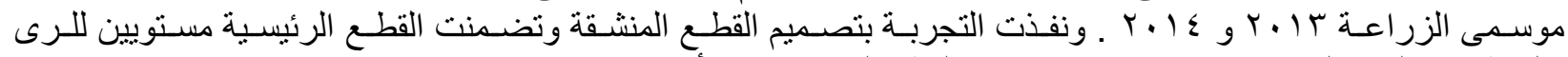

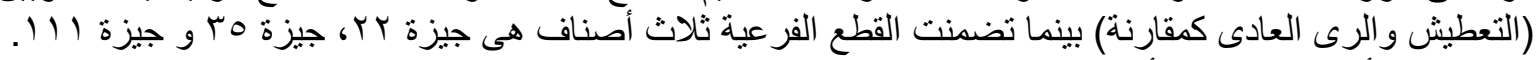

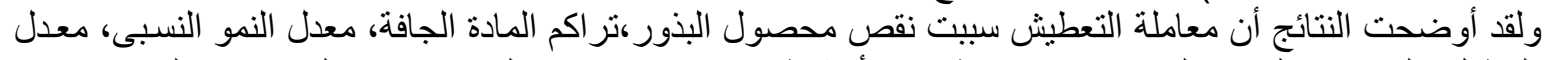

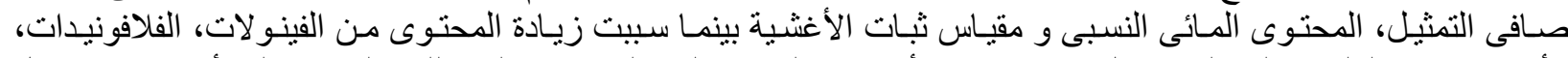

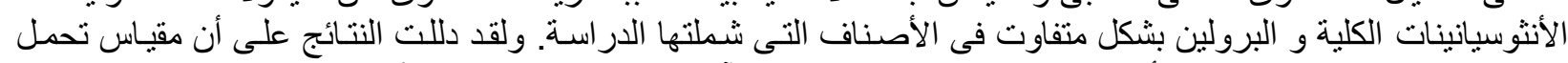

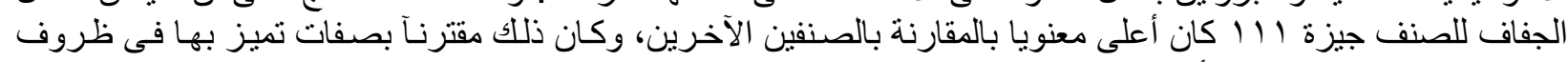

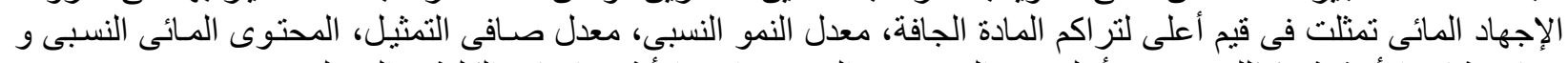

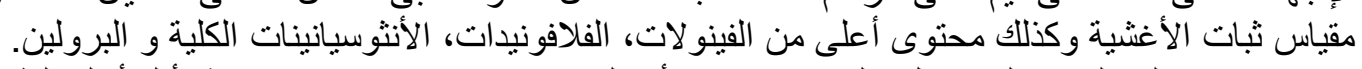

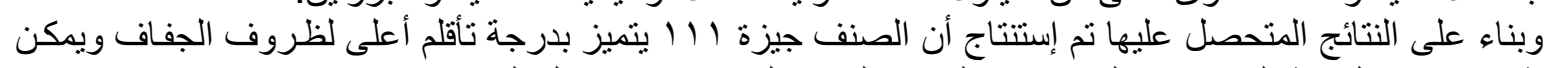

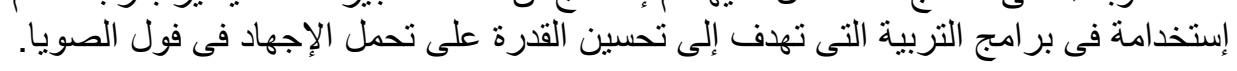

